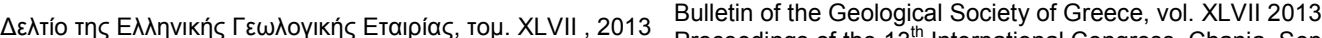

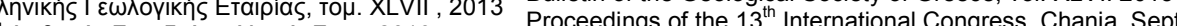

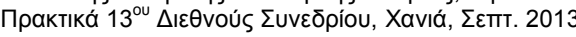
2013

\title{
SEDIMENTATION PROCESSES AND PALAEOGRAPHIC EVOLUTION OF MAKRILIA PLIOCENE DEPOSITS, SE CRETE
}

\author{
Moforis L. ${ }^{1}$, Kostopoulou S. ${ }^{2}$, Panagopoulos G. ${ }^{3}$, Pyliotis I. ${ }^{3}$, Triantaphylou \\ M. $^{2}$, Manoutsoglou E. ${ }^{3}$ and Zelilidis A. ${ }^{1}$ \\ ${ }^{1}$ University of Patras, Department of Geology, Laboratory of Sedimentology, Patra, 26110, \\ Greece, a.zelilidis@upatras.gr \\ ${ }^{2}$ National \& Kapodistrian University of Athens, Faculty of Geology \& Geo-Environment, \\ Department of Historical Geology - Paleontology, Athens, 15784, Greece, mtriant@geol.uoa.gr \\ ${ }^{3}$ Technical University of Crete, Department of Mineral Resources Engineering, Research Unit of \\ Geology, Chania, 73100, Greece, emanout@mred.tuc.gr
}

\begin{abstract}
Detailed sedimentological analysis in Makrylia cross-section deposits showed at least five coarsening-upward cycles that were developed in a shelf environment. The main lithology is sandy silt and the sediments were transported as homogenous suspension in a low energy environment that deposited in a shallow water basin. The content of calcium carbonate $\left(\mathrm{CaCO}_{3}\right)$ is low and tends to increase to the coarsegrained clasts. Organic carbon (TOC) measurements showed the presence of many samples with high content in TOC suggesting potential hydrocarbon source rocks. There is mostly a negative correlation between $\mathrm{CaCO}_{3}$ and TOC introducing generally anoxic conditions. Biostratigraphic analysis showed that the studied deposits are of Pliocene age that were precipitated in alternating conditions of oxic-anoxic events. According to the above results and taking into account previous results from the surrounding sediments it seems that the studied deposits accumulated in a shallow, low energy, intra-mountain basin at the margins of the main Ierapetra basin. Key words: Makrylia, $\mathrm{TOC}, \mathrm{CaCO}_{3}$, grain-size analysis, biostratigraphy.
\end{abstract}

\section{Пєрí $\eta \psi \eta$}

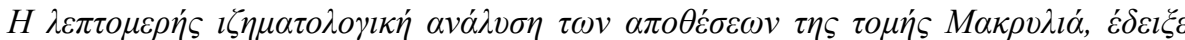

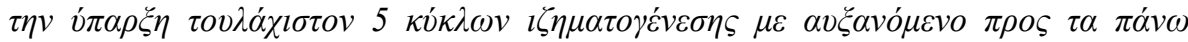

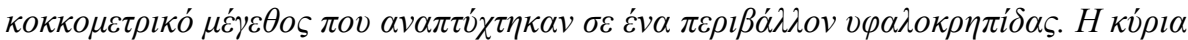

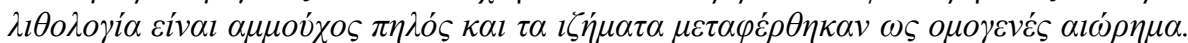

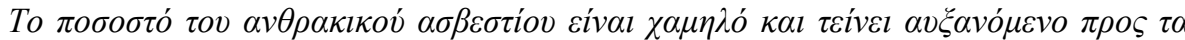

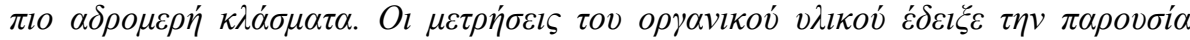

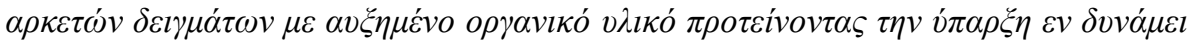

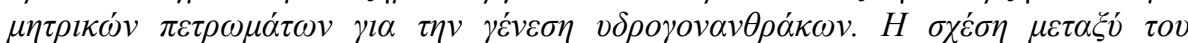

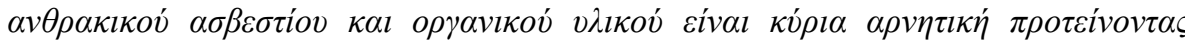

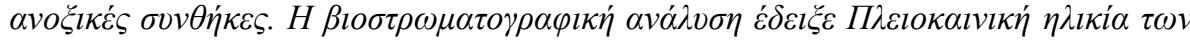

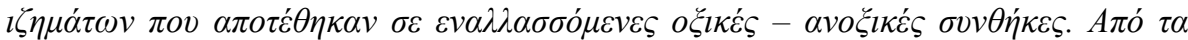

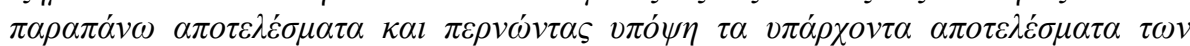

$\underline{\text { XLVII. No } 1-216}$ 


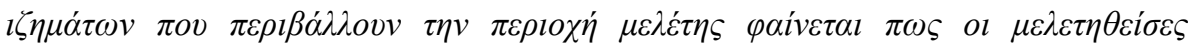

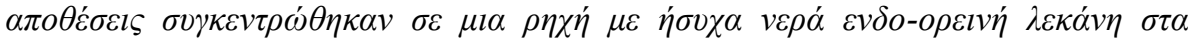

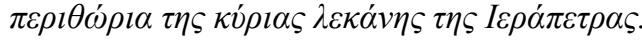

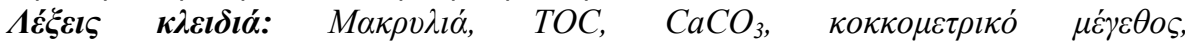

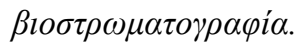

\title{
1. Introduction
}

The grain size analysis, aims to determine the lithology and grain size parameters in order to understand the depositional conditions. Continental shelves constitute one of the preferential zones for the productivity of biomass (Biju-Duval, 2002) which is converted into hydrocarbons. Source rock prediction requires an understanding of the structural and stratigraphic evolution of the sedimentary succession within a basin. Characterizing the organic matter from sedimentary rocks is now widely recognized as a critical step in the evaluation of the hydrocarbon potential (Lafargue et. al., 1998). According to Hauck et al., (2012), $\mathrm{CaCO}_{3}$ distribution and contribution to the marine carbon cycle is connected to environmental parameters as water depth, width of the shelf and primary production. Under conditions of intense sedimentation the amount of calcium carbonate increases towards the finer fractions (delta-rivers) and in marine sediments with low sedimentary rate, where carbonate material increases to the coarse fractions (Saadellah and Kukal, 1969).

In this paper a cross-section in Makrylia area was studied in detail, where 36 samples were analysed in order to determine grain-size, $\mathrm{TOC}$ and $\mathrm{CaCO}_{3}$ content, and the age of the sediments.

\section{Geological Setting}

The Ierapetra graben has an asymmetric architecture with the oldest deposits generally outcropping in the south (Figure 1). The pre-Neogene rocks surrounding the western Ierapetra graben are, from younger to older, the Upper unit, the Pindos unit, the Tripolitza unit, PhylliteQuartzite Series and the Plattenkalk Group (see Creutzburg et al., 1977, for description of units). According to Fortuin and Peters (1984), the pebbles in the Mithi Formation were almost exclusively derived from the Upper unit, whereas the pebbles in the overlying Males Formation are dominantly from the Pindos unit. The overlying Early Tortonian Breccia Series contains debris from the Tripolitza unit. The above indicate progressive exhumation of footwall units during graben development.

Neither thickness and grain size, nor the spatial arrangements of the cobbles of Mithi Formation sediments have a distinct relationship to graben-related faults (ten Veen and Postma, 1999). The sediments of the Males Formation are deposited in alluvial fans, which had their apex against the Kritsa fault zone (Postma et al., 1993), indicating that faulting and deposition of the alluvial fans were related to each other. Therefore, the age of the Males Formation suggests that activity on the Kritsa fault zone commenced in latest Serravallian time (14-12Ma). Fluvial conglomerates of the Males Formation have directed westerly, axial-parallel palaeocurrent directions, whereas breccia deposits close to the larger faults were shed from the north (Postma et al., 1993).

Cross-cutting relationships show that the Kritsa and also the Kroustas fault zones, in the northern Ierapetra graben, are offset by NNE-striking normal faults. In the central and southern Ierapetra graben, the Makrilla and Parathiri fault zones are two major WNW-striking normal faults (Figure 2). The Makrilla fault zone is either cut or cross-cuts these NNE-striking faults, whereas the Parathiri fault zone, further south, mainly cuts the NNE-striking faults. These relationships provide robust evidence that the Kritsa fault zone belongs to the oldest generation of graben-related faults. Along the southern coast, a series of east-west oriented Late Pleistocene marine terraces exist, demonstrating the significant coastal uplift of this area (Gaki-Papanastassiou et al., 2009). 

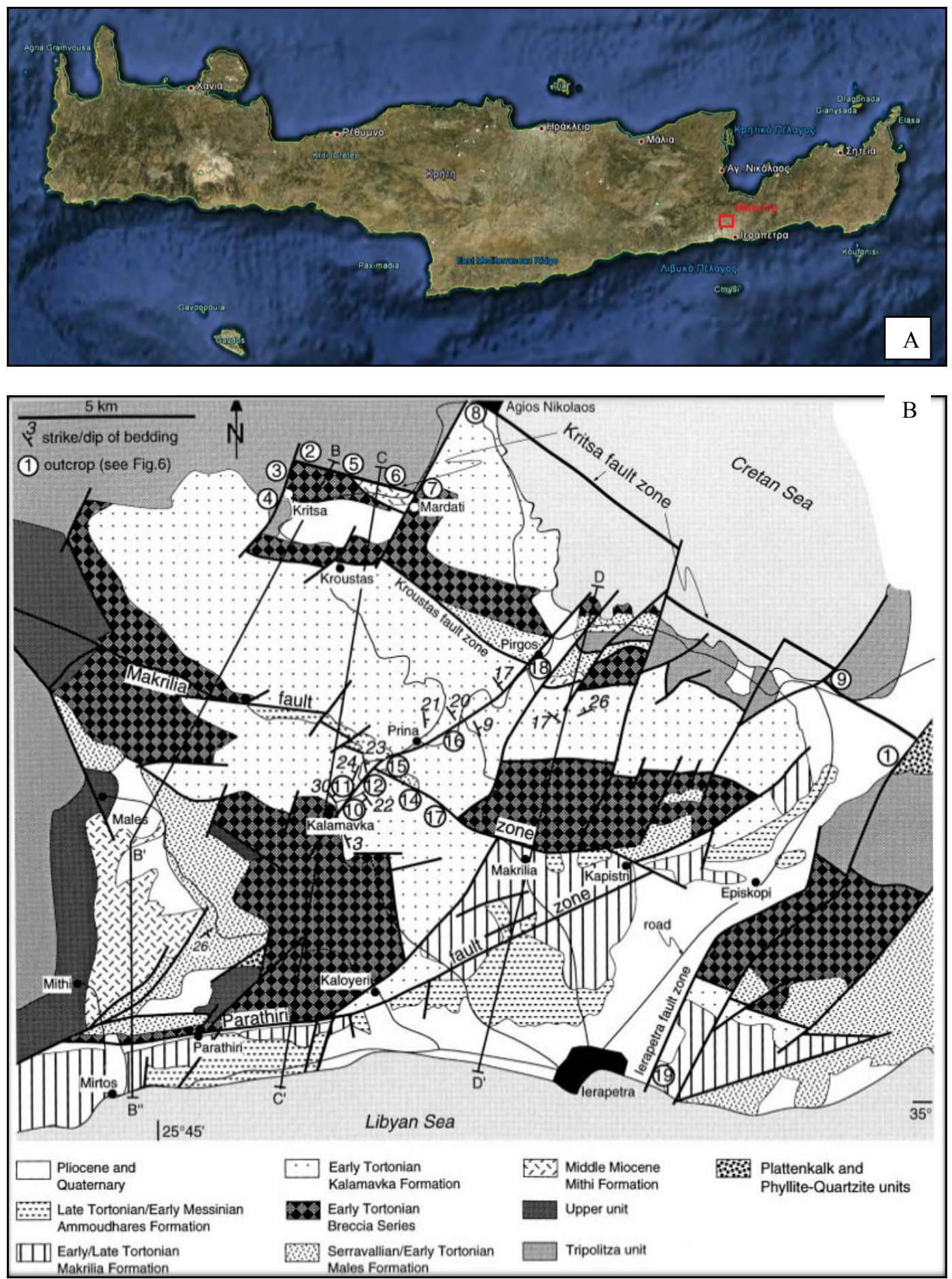

Figure 1 - A) Crete island where the area under study is shown. B) Geological map of Ierapetra graben according to Fortuin \& Peters (1984) and Postma et. al. (1993). 


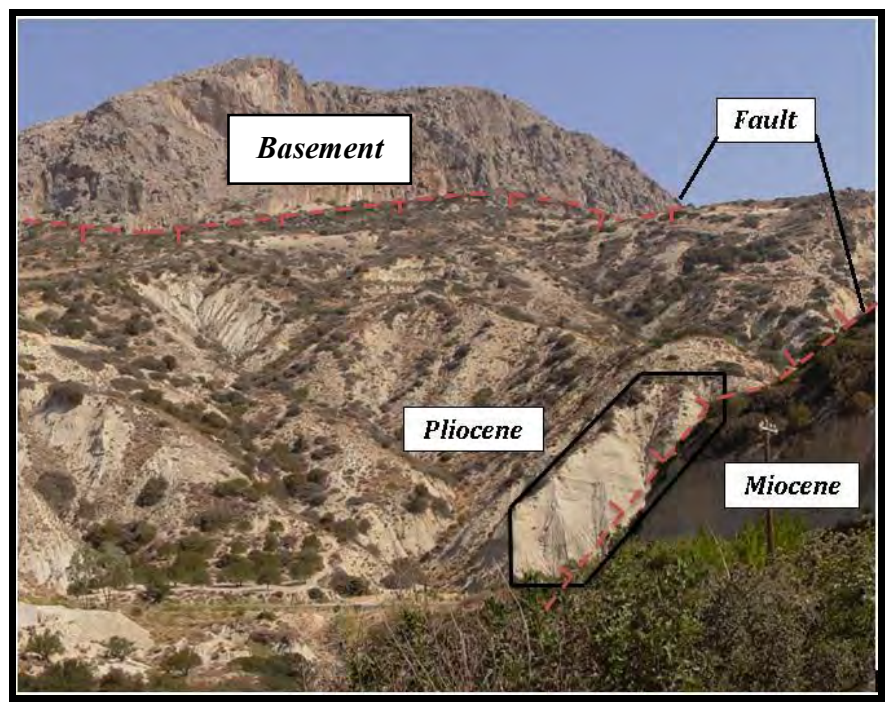

Figure 2 - Makrilia Pliocene deposits accumulated in a fault controlled basin. Box shows the studied cross-section of Figure 3.

\section{Stratigraphy}

\subsection{Lithostratigraphy}

A cross-section up to $48 \mathrm{~m}$ thick was studied, of a total more than $110 \mathrm{~m}$ thick sequence, where five (5) cycles with an upward coarsening trend were observed (Figures 3 and 4). More specifically, each cycle, from the lower to the upper, consists of:

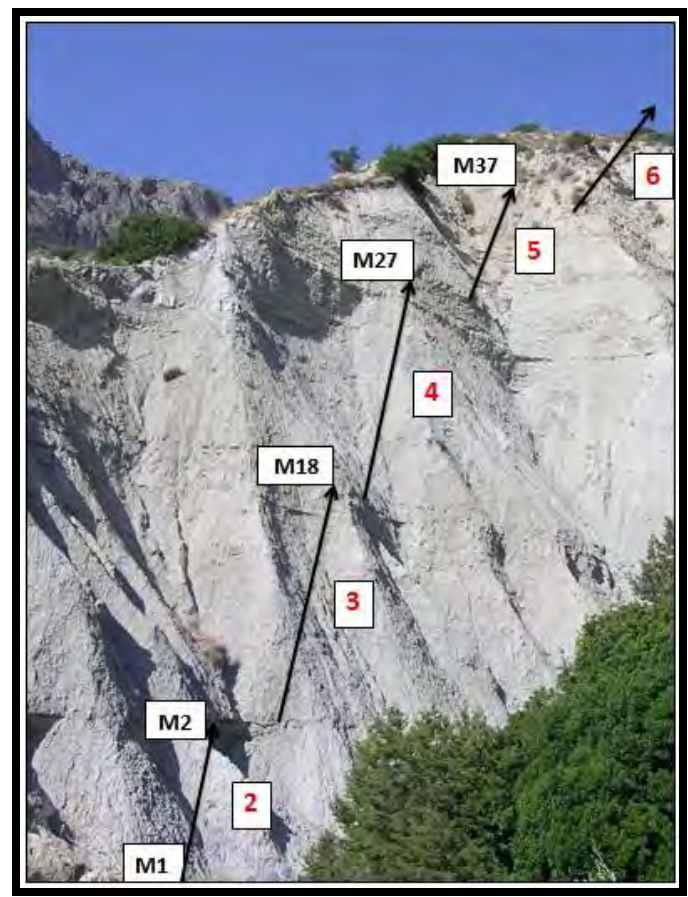

Figure 3 - Panoramic view of the studied cross-section where the upper 5 cycles with coarsening upward trend is shown.

XLVII. No $1-219$ 


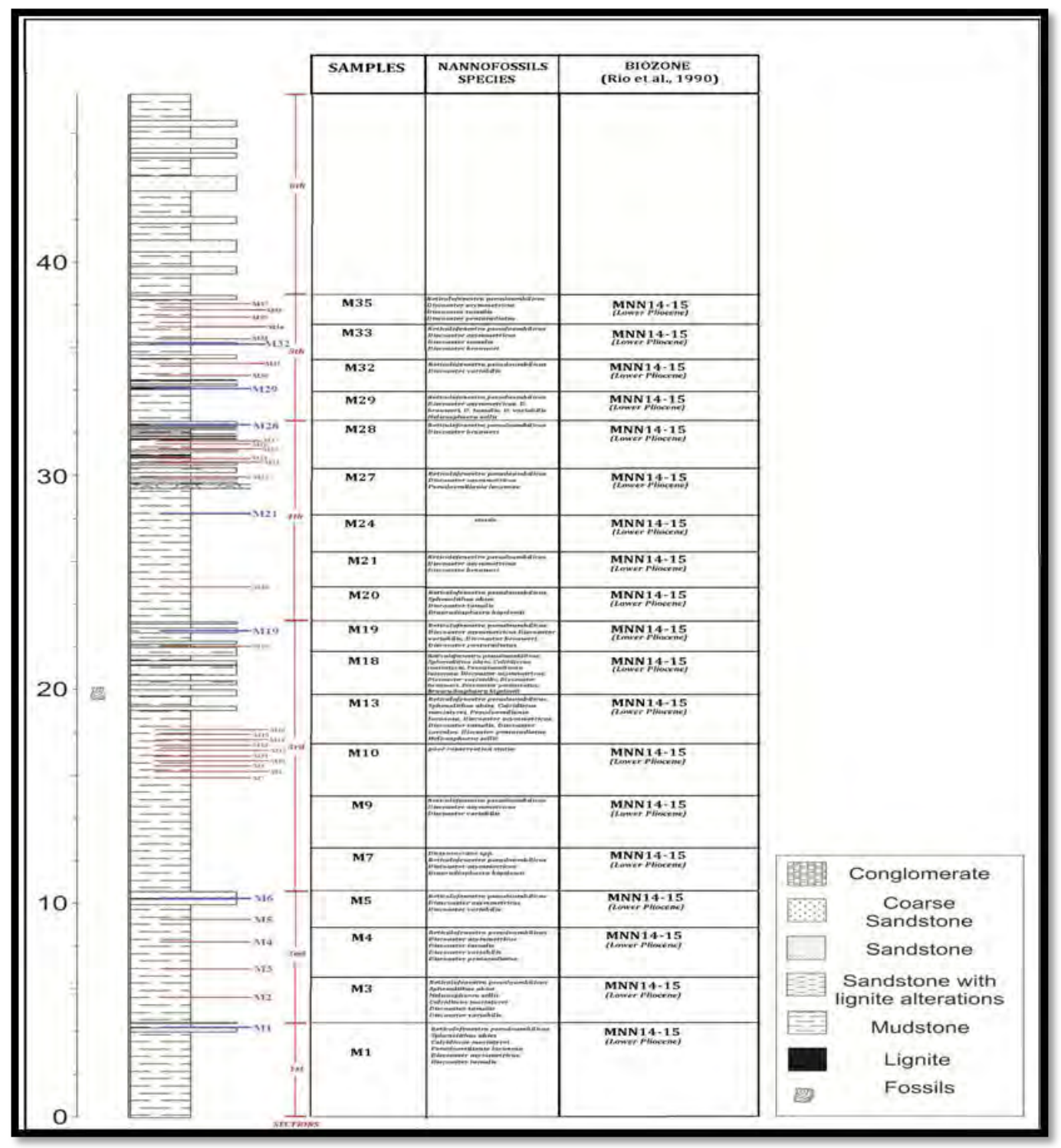

Figure 4 - Stratigraphic description of the studied cross-section.

The first cycle has a total thickness of $4.5 \mathrm{~m}$. The lower part consists of massive grey clay. Within clayey spheroid structures were formed as a result of the rapid water escape through the sediment, indicating rapid sedimentation conditions. The upper part, of a total thickness $40 \mathrm{~cm}$, is composed of two sand beds $(15 \mathrm{~cm}$ and $5 \mathrm{~cm}$ respectively), with a massive white-grey in color clay, up to $20 \mathrm{~cm}$ thick.

The second cycle has a total thickness of $6 \mathrm{~m}$. The lower part consists of massive white to grey siltstone, up to $5.5 \mathrm{~m}$ thick. The cycle ends with sandy deposits, up to $60 \mathrm{~cm}$ thick. These sandy deposits are composed upwards of: $5 \mathrm{~cm}$ coarse sand with a brown-yellow color, next $25 \mathrm{~cm}$ exhibit a fining trend with a brown color, $5 \mathrm{~cm}$ with the presence of four coal horizons of about $1 \mathrm{~cm}$ each in thickness, a $4 \mathrm{~cm}$ thick fossiliferous horizon, and finally $26 \mathrm{~cm}$ of light to dark sand with sparce pebbles.

The third cycle has a total thickness of $12 \mathrm{~m}$. The lower part, up to $8 \mathrm{~m}$ thick, consists of siltstones, with white, dark blue, grey and red colors. The upper part, up to $4 \mathrm{~m}$ thick consists of interbedded 
sand, mud and coal beds. Coal beds thickness ranging from 1 to $2 \mathrm{~cm}$, whereas the thickness of sand deposits is ranging from 2 to $10 \mathrm{~cm}$.

The fourth cycle, up to $10 \mathrm{~m}$ thick, is composed of massive gray siltstone at the lower $6 \mathrm{~m}$ and thin interbedded sand - mud and coal beds in the upper $4 \mathrm{~m}$. Within this upper part a conglomeratic bed up to $20 \mathrm{~cm}$ was formed. Coal interbeds, up to 13 horizons, have an average thickness $1 \mathrm{~cm}$, whereas sand/mud ratio range from 1:1 to $1: 2$.

The fifth cycle has a total thickness of about $6 \mathrm{~m}$. The lower part consists of massive mud and the upper part of sand and coal beds, with $5-10 \mathrm{~cm}$ thick.

The uppermost studied cycle (sixth cycle) has a total thickness up to $10 \mathrm{~m}$, and consists of massive sand-mud beds. Over the sixth cycle and for the next $15 \mathrm{~m}$, although it was difficult to analyze or to select samples, it seems that there is a continuity of sand-mud interbeds.

Finally, as a general conclution, it seems that there is an upward increase both in the thickness of sandy beds and in grain size.

\subsection{Biostratigraphy}

The analysis of the samples (total samples: 36), showed the following species of nannofossils (Figure 4): Reticulofenestra pseudoumbilicus (in abundance over 10\%), Discoaster asymmetricus, Discoaster tamalis, Discoaster pentaradiatus, Discoaster brouweri, Discoaster variablis, Helicosphaera sellii, Pseudoemiliana lacunosa, Sphenolithus abies, Braarudospaera bigelowii, Calcidiscus macintyrei, Discoaster surculus, Dictyococcites spp. According to the above and in relation with the biochronological data for the calcareous data of the Mediterranean (Lourens et al., 2004), the age of Makrilia's section placed between 4.12Ma-3.84Ma (biozone MNN14-15, Rio et al., 1990), which corresponds to the age of Lower Pliocene.

\section{Laboratory Analysis and Results}

\subsection{Grain Size Analysis}

The grain size analysis (sieve and pipette method) aims to determine the lithology, whereas grain size parameters, according to Folk and Ward (1957) methodology, were used in order to determine depositional conditions.

The grain size analysis showed that the main lithology is sandy clay. The diagram of Passega (1969), showed that sediment transportation was mostly as a uniform suspension. According to Stewart's diagram (1958), samples are close to the stagnant waters, whereas according to Valia \& Cameron (1977) and Moiola \& Visher (1968), sedimentation took place in low basin depths (Figures 5,6 and 7).

\section{2. $\mathrm{CaCO}_{3}$ Method and Results}

For the determination of the \% content of calcium carbonate $\left(\mathrm{CaCO}_{3}\right)$, the method for the calcium carbonate $\left(\mathrm{CaCO}_{3}\right)$ decomposition with acetic acid $\left(\mathrm{CH}_{3} \mathrm{COOH}\right)$ was used, as described by Varnavas (1979).

Calcium carbonate content of the Makrilia studied sediments exhibits variable contents ranging from $11,26 \%$ to $37,26 \%$, with an average value of $20,17 \%$ (Figure 8 ). At the first sedimentary cycle (sample M1), is only one sample with a $31,01 \%$ percentage of calcium carbonate. At the second sedimentary cycle (samples M2-M6), max value of $\mathrm{CaCO}_{3}$ occurs at M5 (30,25\%), while minimum value occurs at sample M3 (20,40\%). At the third sedimentary cycle (samples M7-M19), a major peak occurs at M7 (31,50\%), while minimum value occurs at M12 (11,26\%). A the fourth sedimentary cycle (samples M20-M28), max value occurs at M25 (37,26\%), while minimum value occurs at M26 (12,8\%). At the fifth sedimentary cycle (samples M29-M37), the maximum value occurs at M34 (23,63\%), while minimum value was observed in the sample M35 $(13,62 \%)$. 


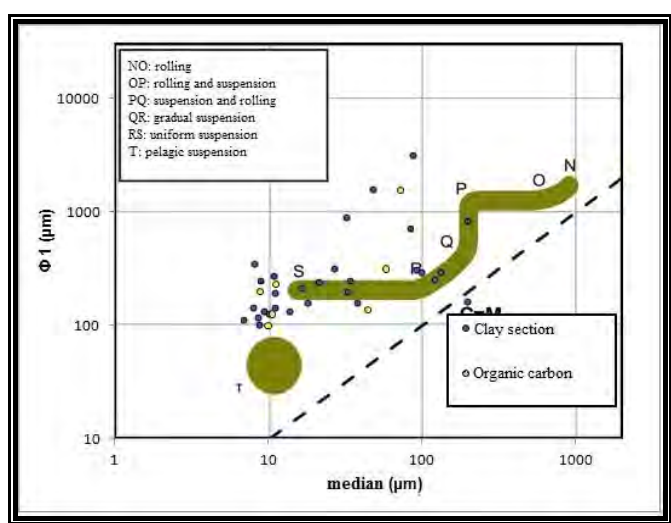

Figure 5 - Diagram of Passega $(1957,1969)$.
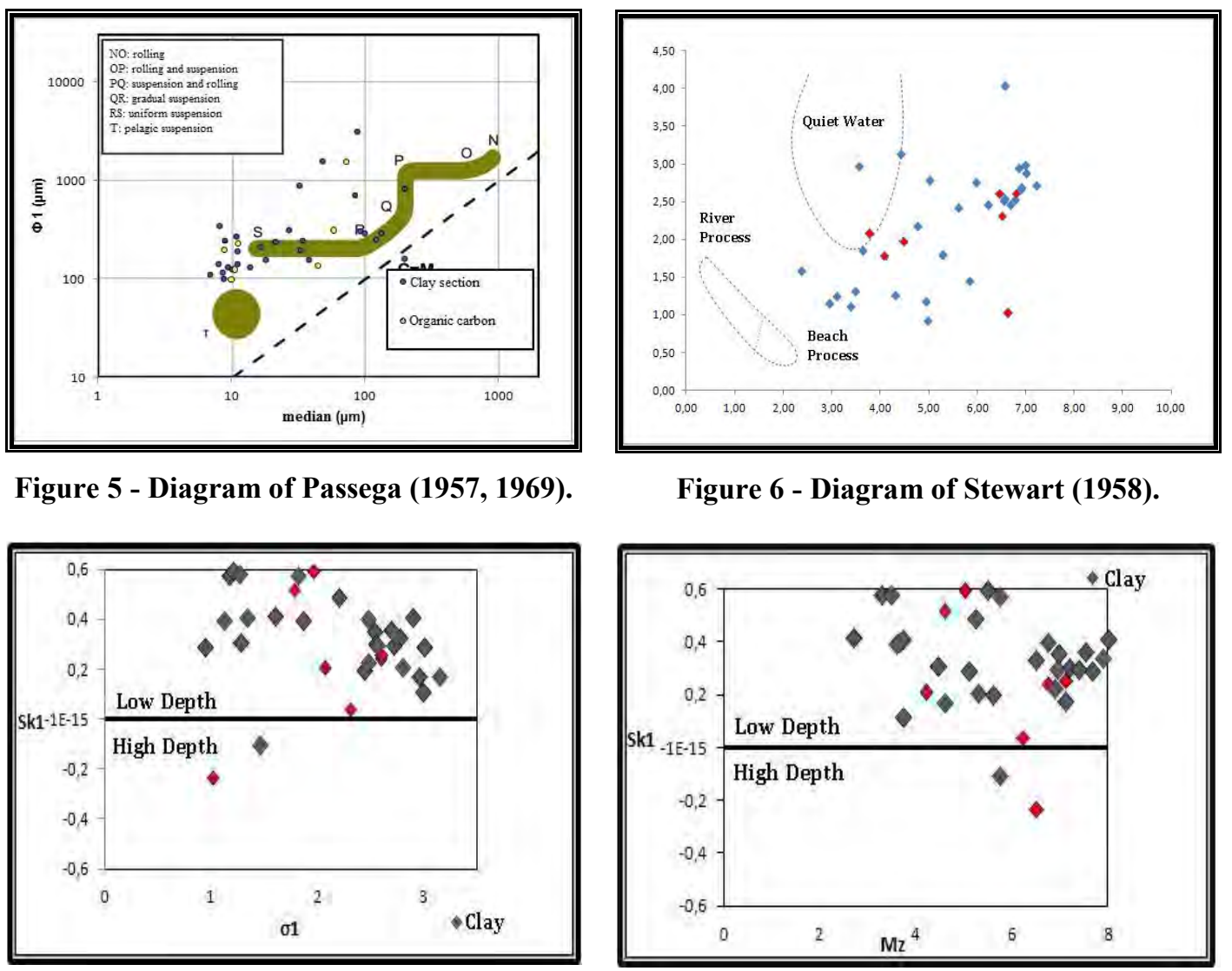

Figure 6 - Diagram of Stewart (1958).

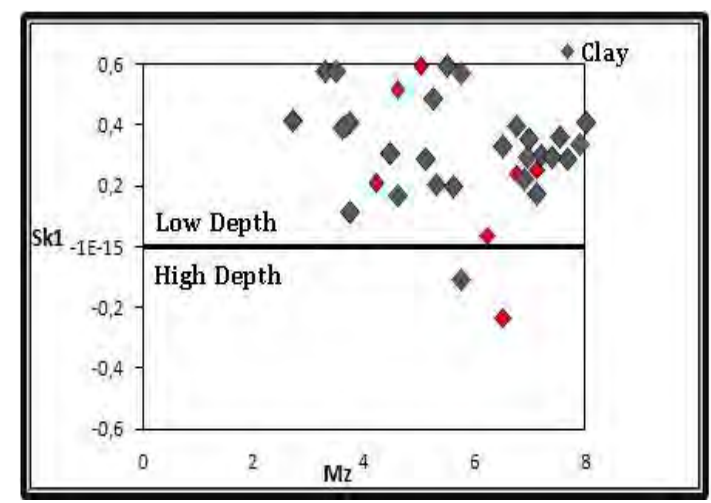

Figure 7 - Diagrams of Valia \& Cameron (1979).

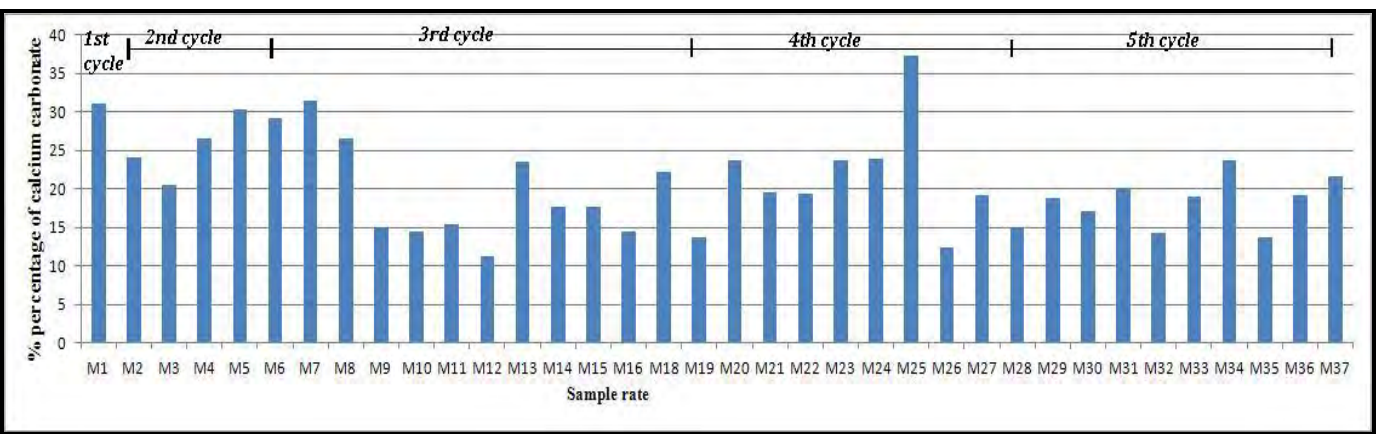

Figure 8 - Calcium carbonate percentages (\%) in sediments of study area.

The analysis of the calcium carbonate showed that the samples are not very rich in calcium carbonate. The increase or decrease of calcium carbonate in sediments shows a sequence of sedimentary conditions. In marine sediments with low sedimentary rate, carbonate material increases to the coarse fractions (Saadellah and Kukal, 1969). In the study area the calcium carbonate ratio is moderate and the percentage of calcium carbonate tends to increase to the coarse clasts. 


\subsection{TOC Method and Results}

The measurement of organic carbon content was based on the method of titration (Gaudette et al., 1974). The analysis showed that the percentage of the contribution of organic carbon in the samples ranged from $0 \%$ to $2.26 \%$ with an average value of $0,41 \%$ (Figure 9). At the first sedimentary cycle (sample M1), we have only one sample with a value at $1,15 \%$. At the second sedimentary cycle (samples M2-M6), max value occurs at M6 (1,71\%), while minimum value occurs at M2 (0,02\%). At the third cycle (samples M7-M19), maximum value occurs at M19 $(2,27 \%)$, while minimum value correspond to M8 (0\%). At the fourth sedimentary cycle (samples M20-M28), max value occurs at M28 (1,13\%), while minimum value occurs at M24 (0\%). At the fifth sedimentary cycle (sample M29-M37), max value occurs at M35 (2,06\%), while minimum value occur at M37 (0,1\%).

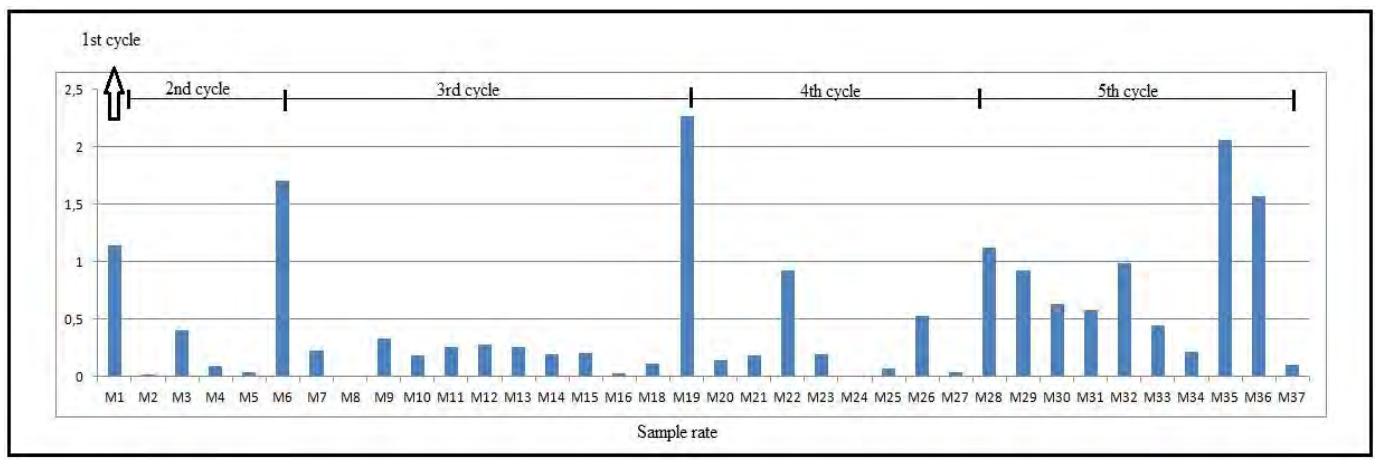

Figure 9 - Organic carbon percentages $(\%)$ in sediments of study area

The analysis of organic carbon showed that several samples are of particular interest in organic carbon. The organic carbon content shows depositional conditions (Folk, 1968). In the open shelf environment the content of the organic carbon is less than $1 \%$, while at a lagoon is more than $1 \%$ (Kukal 1971). In marine sediments TOC ranged from $0.5-1 \%$, while in coastal sediments content ranges from $1-5 \%$ (Trask 1939). In study samples many samples showed high TOC content indicating possible source rocks.

\subsection{Correlation Between TOC-CaCO}

A synthetic diagram of organic carbon and calcium carbonate contents was constructed in order to compare results. From the correlation diagram (Figure 10) we can observe that generally there is an inverse correlation between those two parameters. Either an increase of organic carbon and reduce of calcium carbonate, or a decrease of organic carbon and an increase of calcium carbonate. The first case is related with anoxic conditions whereas the second case is related to oxic conditions due to which organic carbon is oxidised, while the oxidizing environment favours the precipitation of carbonates resulting in increased $\mathrm{CaCO} 3$ contents.

\subsection{Correlation Between (TOC-CaCO$)_{3}$ )- Benthic Foraminifera}

The detailed analysis of benthic foraminifera in samples M6 and M28, where the organic carbon increases and the calcium carbonate reduces indicating a low oxygen environment, showed that the benthic foraminifera of M6 consists of markers of oxygenated water, whereas the benthic foraminifera of sample M28 are characteristic for environments with low oxygen conditions.

The above correlation depicts the necessity of a more detailed investigation for the sedimentation's conditions and a more detailed sedimentary interpretation of the relationship between TOC$\mathrm{CaCO} 3$ and the environmental conditions, as is recommended by the benthic foraminifera. 


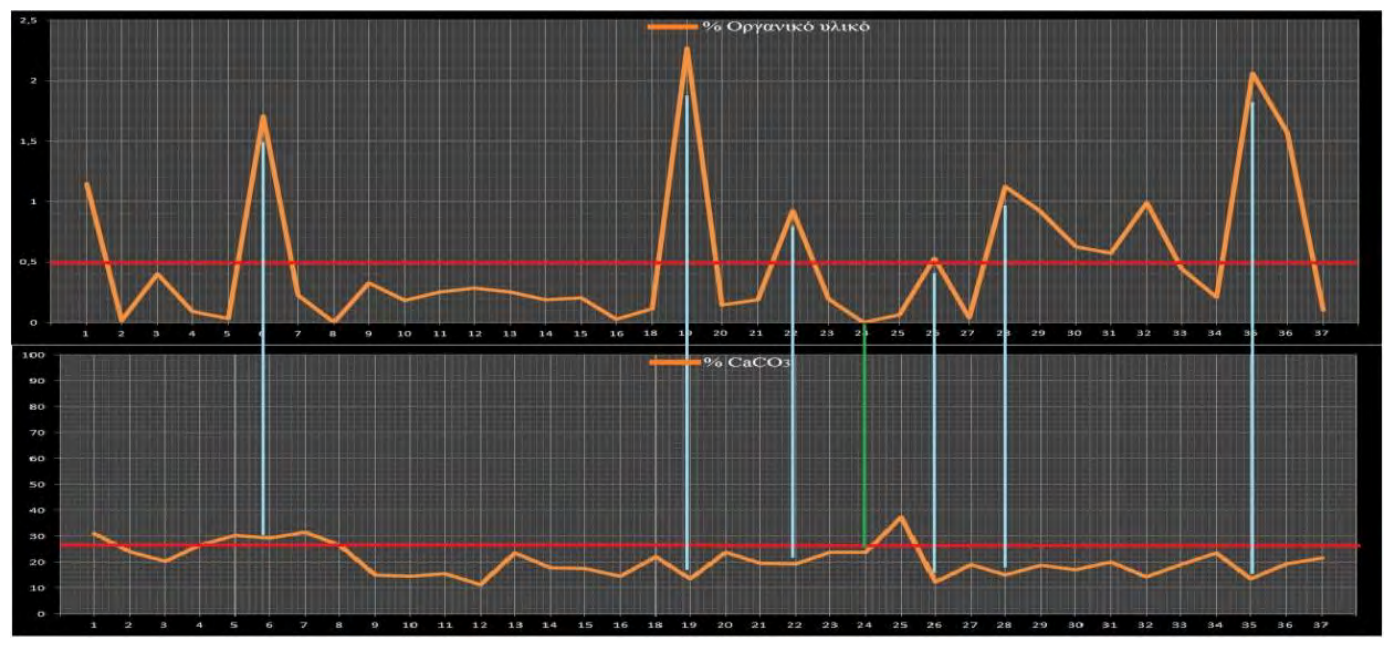

Figure 10 - Correlation diagram between $\mathrm{TOC}$ and $\mathrm{CaCO}_{3}$.

\section{Conclusion}

Detailed sedimentological analysis showed low sedimentation rates in a low energy environment. Depositional environment was an intra-mountain basin formed during early Pliocene as a trench due to the WNW trending normal faults activity. The main lithology is sandy clay and the sediments transported mostly as a uniform suspension.

Organic carbon analysis showed that many samples have a high TOC content and could be act as source rocks for hydrocarbon generation.

The inverse correlation between $\mathrm{TOC}-\mathrm{CaCO}_{3}$ is owed to different depositional conditions (sometimes oxic and some others anoxic).

The detailed study of benthic foraminifera in two samples showed that the results of the above inverse correlation between TOC $-\mathrm{CaCO}_{3}$ must be reexamined and the use of benthic foraminifera must support the above correlation.

Finally, and taking into account the above results and the presence of at least 6 cycles with coal beds in the top of each cycle, we could suggest the existence of a protected intra-mountain basin that it's connection with the major basin was at least six times disturbed, producing semi closed shallow marine conditions.

Since Pliocene basins south of Crete are potential hydrocarbon fields a detailed analysis of Pliocene deposits in outcrops of south Crete is necessary.

\section{Acknowledgments}

This research has been co-financed by the European Union (European Social Fund - ESF) and Greek national funds through the Operational Program "Education and Lifelong Learning" of the National Strategic Reference Framework (NSRF) - Research Funding Program: THALIS -UOA"Messinian Salinity Crisis: the greatest Mediterranean environmental perturbation and its repercussions to the biota" (70/3/11605, MIS: 375405).

\section{References}

Biju-Duval B. 2002. Sedimentary Geology. Sedimentary Basins, Depositional Environments, Petroleum Formation: xiii + 642 pp. Paris: Editions Technip. 
Gaki-Papanastassiou K., Karymbalis E., Papanastassiou D. and Maroukia H. 2009. Quaternary marine terraces as indicators of neotectonic activity of the Ierapetra normal fault SE Crete (Greece), Geomorphology, 104, 38-46.

Gaudette H.E., Flight W. R., Toner L. and Folger D.W. 1974. An inexpensive titration method for the determination of organic carbon in recent sediments, Jour. Sed. Petr., 44, 249-253.

Creutzburg N., Drooger C.W. and Meulenkamp J.E. 1977. Geological map of Crete (scale 1: 200.000), Institute of Geology and Mineral Exploration (IGME), Athens.

Fortuin A.R. and Peters J.M. 1984. The Prina complex in Eastern Crete and its relationship to possible Miocene strike-slip tectonics, J. Struct. Geol., 6, 459-476.

Folk R. L. 1968. Petrology of Sedimentary Rocks, Hemphill Publishing Co, Austin, Texas, 170 pp.

Folk R. L. and Ward, W.S. 1957. Brazos river bar: a study in the significance of grain size parameters, Jour. Sed. Petr., 27, 3-26.

Hauck J., Gerdes D., Hillenbrand C.D., Hoppema M., Kuhn G., Nehrke G., Völker Ch. and WolfGladrow D. 2012. Calcium carbonate content in surface sediments and benthic fauna on Antarctic shelves, supplement to: Hauck J., Gerdes D., Hillenbrand C. D., Hoppema M., Kuhn G., Nehrke G., Völker Ch. and Wolf-Gladrow D. 2012: Distribution and mineralogy of carbonate sediments on Antarctic shelves, Journal of Marine Systems, 90 (1), 77-87; PANGAEA - Data Publisher for Earth \& Environmental Science. http://dx.doi.org/10.1594/PANGAEA.757933

Kukal Z. 1971. Geology of recent sediments, Academic Press London and New York, 490 pp.

Lafargue E., Marquis, F. and Pillot D. 1998. Rock-Eval 6 applications in hydrocarbon exploration, production and soil contamination studies, Rev. Inst. Fr. Pét. 53/4, 421- 437.

Lourens L. J., Hilgen F. J., Laskar J., Shackleton N. J. and Wilson D. 2004. The Neogene Period. In: Gradstein, F. M., Ogg, J. G., Smith, A. G. (Eds.), A Geologic Time Scale 2004. Cambridge University Press, Cambridge, 409-440 pp.

Moiola R.J. and Visher D. 1968. Textural parameters: an evaluation, Jour. Sed. Petr., 260, 45-63.

Passega R. 1957. Texture as characteristic of clastics deposition, Am. Soc. Asoc. Petrol. Geol. Bull., 41, 1952-1984.

Passega R. and Byramjee R. 1969. Grain size image of Clastic deposits, Sedimentology, 13, 233253.

Postma G., Fortuin A. R. and van Wamel W.A. 1993. Basin-fill patterns controlled by tectonics and climate: the Neogene "fore-arc" graben of eastern Crete as a case history, Spec. Publs Int. Ass. Sediment., 20, 335-362.

Ring U., Layer P. W. and Reischmann T. 2001. Miocene high-pressure metamorphismin the Cyclades and Crete, Aegean Sea, Greece: Evidence for large magnitude displacement on the Cretan detachment, Geology, 29, 395-398.

Saadellah A. and Kukal Z. 1969. Grain size and carbonate content in costal sediment of Iraq, Jour. Iraq G. Soc, 2, 3-10.

Stewart H. B. and Jr 1958. Sedimentary reflections of depositional environments in San Miguel Lagoon, Baja California, Mexico, Am. Assoc. Petr. Geol. Bull., 42, 2567-2618.

ten Veen J. H. and Postma G. 1999. Neogene tectonics and basin fill patterns in the Hellenic outerarc (Crete, Greece), Basin Res., 11, 223-241.

Trask P. D. 1939. Organic content of recent marine sediments, Recent marine sediments, 428- 453.

Valia H S., and Cameron B. 1977. Skewness as a Paleoenvironmental indicator, Jour. Sed. Petr., 47, 2, 784-793.

Varnavas S. P. 1979. Geochemistry of sediments from the eastern Pacific, Ph.D. Thesis, University London, 431 pp. 